\title{
Correlation between index panoramic radiomorfometric and primary stability of implants
}

\author{
Correlação entre índices radiomorfométricos panorâmicos e estabilidade primária de implantes
}

Rodrigo Alves RIBEIRO'

(iD) ORCID iD 0000-0003-3131-3678

Jorge de Sá BARBOSA'

(i) ORCID iD 0000-0003-4310-9973

José Márcio Barbosa Leite do AMARAL

(iD) ORCID iD 0000-0003-3127-3389

Carlos Renato FRANCO2

(D) ORCID iD 0000-0002-8930-7273

Arthur Rodriguez Gonzalez CORTES 3

(D) ORCID iD 0000-0001-6591-7256

Claudio COSTA 4

(i) ORCID iD 0000-0003-2831-8670

\section{ABSTRACT}

\section{Objective}

To evaluate the correlation between panoramic radiomorphometric index of bone density, stability quotient and the insertion torque of the implant

\section{Methods}

A total of 97 implants were analyzed. Panoramic radiographs calculated the Panoramic Mandibular Index and the Mental Index, in addition to the evaluation of the Mandibular Cortical Index. The insertion torque and the stability quotient of the implant were recorded during the surgical moment. The correlation analysis between the variables described above was performed using the Spearman test, at a significance level of $5 \%$.

\section{Results}

Significant correlations were found between age and mandibular cortical index ( $p=0.000$ and $r=0.429)$, insertion torque and age $(p=0.011$ and $r=0.263)$, stability quotient of the implant in the Vestibulo-Lingual direction and The mesio-distal direction $(p=0.000$ and $r=0.582)$, mandibular and mental panoramic index $(p=0.000$ and $r=0.809)$, mandibular and mental cortical index $(p=0.005$ and $r=-0.288)$ and mandibular cortical index Mandibular panoramic view $(p=0.000$ and $r=-0.366)$. All other correlations were not significant $(p<0.05)$.

\section{Conclusion}

The results of this work suggest that the panoramic radiomorphometric indices may contribute to the pre-diagnosis of the primary stability of dental implants.

Indexing terms: Bone density. Dental implants. Indexes.

\section{RESUMO}

\section{Objetivo}

Avaliar a correlação entre índices radiomorfométricos panorâmicos de densidade óssea, quociente de estabilidade e o torque de inserção do implante.

\section{Métodos}

Foi analisado um total de 97 implantes. Nas radiografias panorâmicas, foram calculados os índices Panorâmico Mandibular e o índice Mentual, além da avaliação do índice Cortical Mandibular. O torque de inserção e o quociente de estabilidade do implante foram registrados durante o momento cirúrgico. A análise de correlação entre as variáveis descritas acima foi realizada com por meio do teste de Spearman, a um nível de significância de $5 \%$.

\section{Resultados}

Foram encontradas correlações significantes entre as variáveis idade e o índice Cortical Mandibular ( $p=0.000$ e r=0.429), torque de inserção e a idade $(p=0.011$ e $r=0.263)$, quociente de estabilidade do implante na direção Vestibulo-Lingual e a direção Mesio-Distal ( $p=0.000$ e $r=0.582)$, índice panorâmico mandibular e o mentual ( $p=0.000$ e $r=0.809$ ), índice cortical mandibular e o mentual ( $p=0.005$ e $r=-0.288)$ e índice cortical mandibular e o panorâmico mandibular ( $p=0.000$ e $r=-0.366)$. Todas as outras correlações não foram significantes $(p<0.05)$.

\footnotetext{
${ }^{1}$ Universidade Metropolitana de Santos. Av. Conselheiro Nébias, 518, 11015-001, Paquetá, Santos, SP, Brasil. Correspondência para / Correspondence to: RA RIBEIRO. E-mail: <rodrigo.77@usp.br>.

${ }^{2}$ Faculdade São Leopoldo Mandic - Unidade São Paulo, Programa de Pós-Graduação em Odontologia. São Paulo, SP, Brasil

${ }^{3}$ Universidade de São Paulo. São Paulo, SP, Brasil.

${ }^{4}$ Universidade de São Paulo, Faculdade de Odontologia, Disciplina de Radiologia. São Paulo, SP, Brasil.

$\mathbf{v} \mathbf{v}$

Como citar este artigo / How to cite this article

Ribeiro RA, Barbosa JS, Amaral JMBL, Franco CR, Cortes ARG, Costa C. Correlation between index panoramic radiomorfometric and primary stability of implants. RGO, Rev Gaúch Odontol. 2018;66(3):219-224. http://dx.doi.org/10.1590/1981-863720180003000043350
} 
Conclusão

Os resultados deste trabalho sugerem que os índices radiomorfométricos panorâmicos podem contribuir para o pré-diagnóstico da estabilidade primária de implantes dentários.

Termos de indexação: Densidade óssea. Implantes dentários. Índices.

\section{INTRODUCTION}

The evaluation of bone density is very important and widely used to diagnose several diseases such as the osteoporosis [1]. In Dentistry, the concern with both bone density and quantity started with the osseointegration findings and the consequent use of dental implants in oral rehabilitation $[2,3]$.

Bone density and lack of movement are the most important parameters to the primary stability of the implant, responsible for the osseointegration during the first stage of the surgical healing [4]. The lack of stability may cause mobility and loss of the implants $[5,6]$. However, almost nothing is known about the objective and the quantitative methods of bone density measurements, which can be applied during the planning of implant surgeries, aiming at predicting the primary stability of the implants to be inserted [7].

In Dentistry, the use of panoramic x-rays is one of the most used radiographic techniques to initially evaluate the patient. This happens because all teeth and supporting structures can be seen in a single film, applying a simple technique with a relative low dose of radiation. In such radiographs, it is possible to carry out measurements which are named radiomorphometric indexes, being described as measurements associated and correlated with the systemic bone mineral density of patients [8]. One of these indexes is called mentual index $(\mathrm{MI})$, described as having a correlation with the bone mineral density of the lumbar spine and the proximal femur [9]. The Ml can be measured using a high precision caliper or, digitally, by a computer program [10].

It was found that subjects presenting systemic bone alterations, such as osteoporosis, also present greater reabsorption and cortical thinning of the mandibular base, being evaluated by the mandibular cortical radiomorphometric indexes (MCl) and $\mathrm{Ml}$ [1121].

Based on the literature review mentioned above, it was considered that there should be a correlation between the radiomorphometric indexes and the implant stability, that can be measured during surgery with the torque insertion ( $\mathrm{TI}$ ) and, after surgery, with the resonance frequency analysis through the implant stability quotient (ISQ) $[22,23]$.

Thus, the objective of this research study was to evaluate the correlation between radiomorphometric indexes of bone density, implant stability quotient and torque insertion.

\section{METHODS}

In this study, 27 subjects from both genders and in the bracket age of 18-73 years of age were evaluated, as well as their $\mathrm{x}$-rays and clinical records. A total of 92 implants were installed in several areas of the oral cavity and in various bone types. Subjects with a medical history of hormone replacement therapy or calcium use with less than six months were excluded from the study. All panoramic radiographs used in this study are from the 'Prosthetic and Implant Clinic' of this University and were taken using a Kodak (R7400 digital panoramic unit (Kodak, Rochester, MA, USA), following the same protocol acquisition $68 \mathrm{kVp}, 8 \mathrm{~mA}$ and 9 seconds exposure time.

The $\mathrm{MCl}$ was determined by a bilateral evaluation with results established in: C1 - clear and sharp posterior mandibular cortical (Figure 1), C2 - endosteal surface presenting semilunar defects (lacunar resorptions) or the surface presenting cortical residuals (Figure 2), C3 extremely porous cortical layer (Figure 3 ).

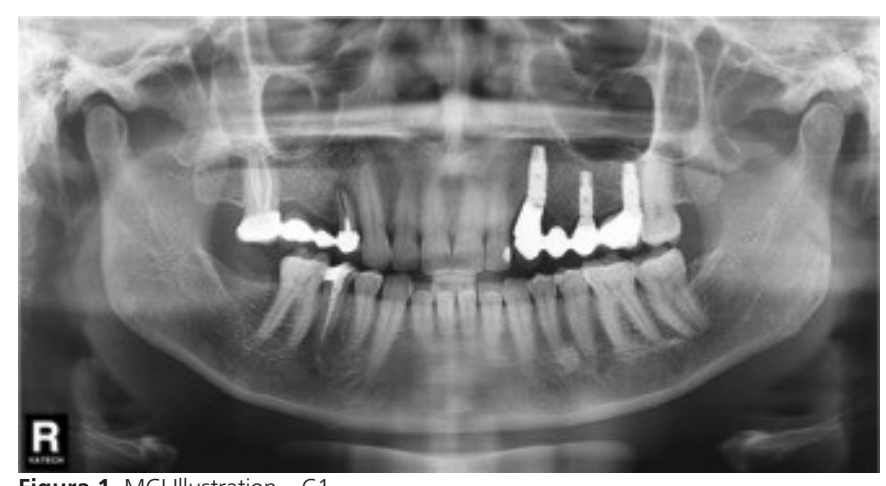




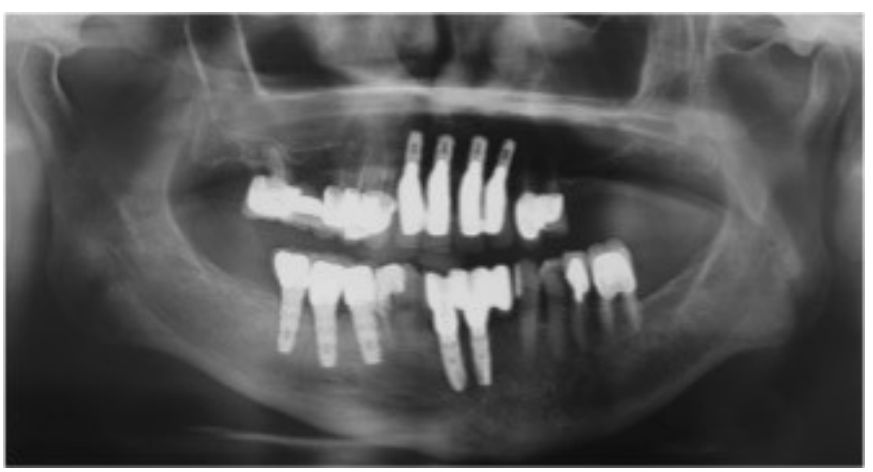

Figura 2. MCl Illustration - C2.

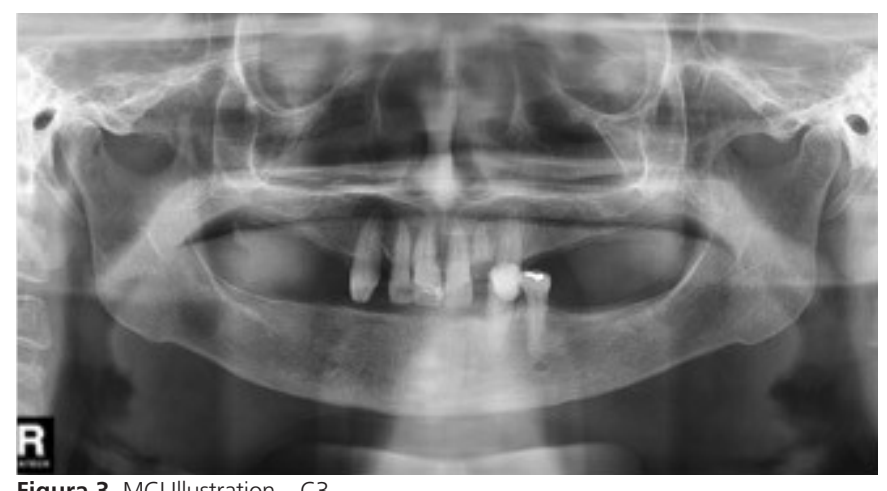

The MPI, following a bilateral evaluation, was determined by the thickness ratio of the mandibular cortical bone, being measured by a perpendicular line to the base of the mandible at the height of the mental foramen center (a), by the distance between the lower border of the mandibular channel and the base of the mandible (b) (Figure 4).

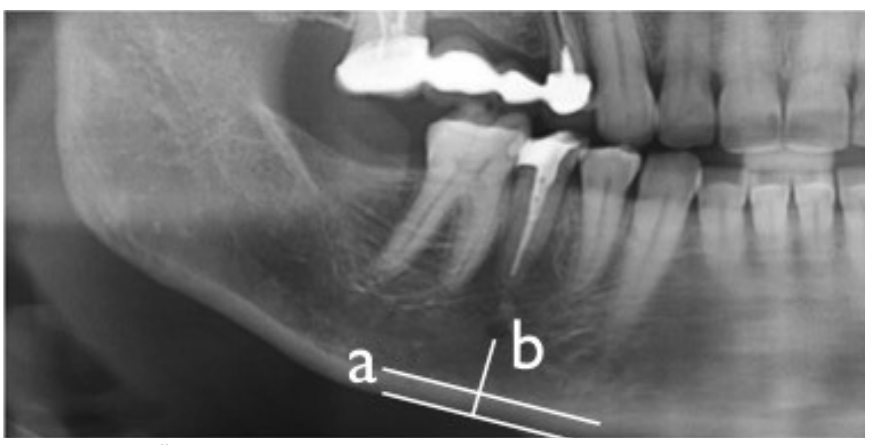

Figura 4. MPI Illustration.

In a bilateral evaluation, the $\mathrm{Ml}$ is determined by the thickness of the mandibular cortical bone, being measured by a perpendicular line to the base of the mandible, at the height of the center of the mentual foramen (Figure 5).

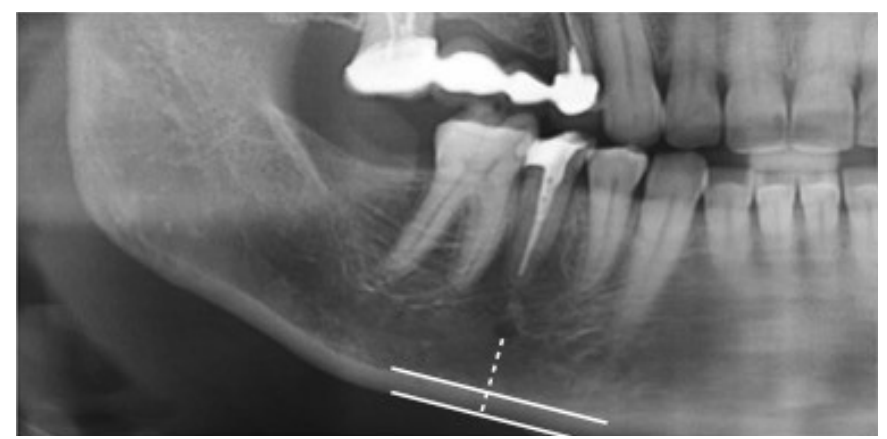

Figura 5. Ml Illustration.

Measurements of MPI and $\mathrm{MI}$ were taken using the calibrated WHITWORTH digital caliper.

The $\mathrm{MCl}, \mathrm{MPI}$ and $\mathrm{MI}$ analyzes were performed by two examiners ( $\mathrm{T} 1$ ), being repeated after seven days (T2). The intra-examiner and the inter-examiner errors were analyzed through the intraclass correlation coefficient (ICC) test, in which the result determined the sensitivity and the specificity for the diagnosis of low bone density.

Regarding the implant insertion surgical procedure, beds were prepared, using the osseointegration drill kit from Conexão Sistemas de Prótese (Arujá, Brazil), and the standard protocol was applied. Osseointegrated implants, from various diameters and lengths, were used for such purpose (AR Torq - Conexão Sistemas de Prótese, Arujá, Brazil), in which the primary stability level was measured by the IT and the ISQ values for the current cases.

The IT measurement was taken using a standard manual torque wrench, so that, after the implant final stabilization, the torque value considered was the one seen on the torque wrench rod when the implant was locked.

After the implant set-up, the primary stability level was measured by the ISQ, verifying the resonance frequency analysis assessed by Osstell ${ }^{\circledR}$ (Integration Diagnostics Ltd., Göteborg, Sweden) and Smartpeg ${ }^{\circledR}$ (Integration Diagnostics Ltd., Göteborg, Sweden). Smartpeg ${ }^{\circledR}$ was selected according to the Smartpeg ${ }^{\circledR}$ reference list, being manually tightened on the implant and measurements taken considering the mesiodistal and buccolingual directions.

Data were submitted to the statistical analysis with 95\% ( $p<0.05)$ and 99\% ( $p<0.01)$ significance levels.

Tables were created and the respective Spearman correlation coefficients calculated.

The intra-observer and inter-observer analysis were evaluated by the ICC (Intraclass Correlation Coefficients).

The study was submitted and approved by the 
Research Ethics Committee of the Metropolitan University of Santos under number 946.661, in compliance with the ethical principles described in the Declaration of Helsinki (2000) and the CONEC Resolution 466/12, being in accordance with the country's laws.

\section{RESULTS}

There was high agreement when evaluating the intra-observer 0.95 ( $p>0.05$ ) and the inter-observer $0.91(p<0.05)$ measurements.
The table below presents the evaluation of the Spearman's correlation coefficient considering age, $\mathrm{Tl}$, ISQ, MI, MPI and $\mathrm{MCl}$. The radiomorphometric indexes were highly correlated among each other. There was an inverse correlation between the IT and the $\mathrm{MCl}(r=$ $-0.239 \mathrm{p}=0.022)$, the Age and the $\mathrm{MCl}(r=0.429 \mathrm{p}=$ $0.000)$ and an inverse correlation between the age and the IT $(r=-0.263 p=0.011)$. The ISQ showed a strong correlation considering the directions and the $\mathrm{Ml}$ and the MPI. The age was correlated with the IT and the $\mathrm{MCl}$.

Quadro 1. Resultados do teste de correlação de Spearman. Sendo que $(*)$ está para significância de correlação de $0,05(p<0,05)$ e $(* *)$ está para significância de correlação de $0,01(p<0,01)$

\begin{tabular}{|c|c|c|c|c|c|c|c|}
\hline & AGE & IT & ISQ M-D & ISQ L-V & $\mathrm{Ml}$ & MPI & $\mathrm{MCl}$ \\
\hline \multirow{2}{*}{ AGE } & & $r=-0.263^{*}$ & $r=0.174$ & $r=-0.013$ & $r=0.153$ & $r=0.170$ & $r=0.429 * *$ \\
\hline & & $p=0.011$ & $p=0.097$ & $p=0.900$ & $p=0.143$ & $p=0.105$ & $p=0.000$ \\
\hline \multirow{2}{*}{ IT } & $r=-0.263^{*}$ & & $r=0.243^{*}$ & $r=0.263$ & $r=0.135$ & $r=0.107$ & $r=-0.239 *$ \\
\hline & $p=0.011$ & & $p=0.019$ & $p=0.011$ & $p=0.199$ & $p=0.309$ & $p=0.022$ \\
\hline \multirow{2}{*}{ ISQ M-D } & $r=0.174$ & $r=0.243^{*}$ & & $r=0.582 * *$ & $r=0.254^{*}$ & $r=0.313^{* *}$ & $r=-0.069$ \\
\hline & $p=0.097$ & $p=0.019$ & & $p=0.000$ & $p=0.014$ & $p=0.002$ & $p=0.511$ \\
\hline \multirow{2}{*}{ ISQ L-V } & $r=-0.013$ & $r=0.263$ & $r=0.582 * *$ & & $r=0.304^{* *}$ & $r=0.263^{*}$ & $r=-0.084$ \\
\hline & $p=0.900$ & $p=0.011$ & $p=0.000$ & & $p=0.003$ & $p=0.011$ & $p=0.423$ \\
\hline \multirow{2}{*}{$\mathrm{Ml}$} & $r=0.153$ & $r=0.135$ & $r=0.254^{*}$ & $r=0.304 * *$ & & $r=0.809 * *$ & $r=-0.288 * *$ \\
\hline & $p=0.143$ & $p=0.199$ & $p=0.014$ & $p=0.003$ & & $p=0.000$ & $p=0.005$ \\
\hline \multirow{2}{*}{ MPI } & $r=0.170$ & $r=0.107$ & $r=0.313^{* *}$ & $r=0.263^{*}$ & $r=0.809 * *$ & & $r=-0.366 * *$ \\
\hline & $p=0.105$ & $p=0.309$ & $p=0.002$ & $p=0.011$ & $p=0.000$ & & $p=0.000$ \\
\hline \multirow{2}{*}{$\mathrm{MCl}$} & $r=0.429 * *$ & $r=-0.239 *$ & $r=-0.069$ & $r=-0.084$ & $r=-0.288 * *$ & $r=-0.366 * *$ & \\
\hline & & $p=0.022$ & $p=0.511$ & $p=0.423$ & $p=0.005$ & $p=0.000$ & \\
\hline
\end{tabular}

\section{DISCUSSION}

Bone density varies with age. Initially, there is a gradual increase of it during childhood, occurring rapidly in adolescence, and continuing to increase until reaching a peak, that can be defined as the maximum amount of bone density that a person accumulates from birth till the skeleton maturity. The skeletal bone density acquired by a person tends to decline after reaching the maximum bone mineral density [1-3].

In this current research study, a moderate correlation of $p<0.01$ between the $\mathrm{MCl}$ and the age was observed through the panoramic radiographs, which allows to conclude that the higher the age the worse the bone condition. Other studies confirm this statement, indicating the use of panoramic radiographies to detect low bone density [9-11].

It was seen an inverse correlation between the TI and the $\mathrm{MCl}$. The higher the insertion torque, the ICM was in $\mathrm{C} 1$, characterizing the mandibular cortical base under normal conditions.

Some authors could predict the initial stability from imaging examination, providing safety to implantologists when treating patients who need rehabilitation through implants. Good initial stability prevents minor movements to occur during the repairing phase, favoring a higher secondary stability and, consequently, osseointegration [22-25].

Contrary to our findings, some authors state that panoramic radiographic images do not provide 
substantial information to diagnose low bone density. In significant samples, it is possible to statistically verify positive correlation between bone mineral density and changes in the mandibular cortical bone by the panoramic radiographic images. In single evaluations, it is not possible to diagnose the risk condition to low bone density for a single person by imaging examination $[26,27]$.

Additionally, in this research study, a high correlation was found between the implant stability quotient (ISQ) and the radiomorphometric indexes (MPI and $\mathrm{MI}$ ). A high correlation was also found considering the three radiomorphometric indexes, which are the mentual index (MI), the mandibular panoramic index (MPI) and the mandibular cortical index $(\mathrm{MCl})(\mathrm{P} \leq 0.01)$. Additional studies have also presented the same results $[20,28]$.

The findings of this study also show a correlation between the $\mathrm{TI}$ and the ISQ in the mesiodistal direction ( $p<0.05)$, as well as a correlation between the radiomorphometric indexes $(p<0.01)$. Another study [29] also showed a correlation among the bone volume, the $\mathrm{TI}$ values and the ISQ of the implant, suggesting that resonance frequency analysis is also a reliable tool to indicate primary implant stability. In agreement with this finding, a similar study concludes that there is a correlation

\section{REFERENCES}

1. Ebbesen EN, Thomsen JS, Beck-Nielsen H, Nepper-Rasmussen HJ, Mosekilde L. Vertebral bone density evaluated by dualenergy X-ray absorptiometry and quantitative computed tomography in vitro. Bone. 1998 Sep;23(3):283-90. doi: 10.1016/S8756-3282(98)00091-X

2. Homolka P, Beer A, Birkfellner W, Nowotny R, Gahleitner A, Tschabitscher $M$, Bergmann $H$. Bone mineral density measurement with dental quantitative $C T$ prior to dental implant placement in cadaver mandibles: pilot study. Radiology. 2002 Jul;224(1):247-52. doi: 10.1148/radiol.2241010948

3. Caula AL, Barbosa EP, Machado FO. Densidade óssea no planejamento em Implantodontia [citado 2017 Mar 3]. Disponível em: <http://www.odontogeral.hpg.ig.com.br/ densidadeossea.htm>.

4. Misch CE. Divisions of available bone in implant dentistry. Int J Oral Implantol. 1990;7(1):9-17.

5. Porter JA, von Fraunhofer JA. Success or failure of dental implants? A literature review with treatment considerations. Gen Dent. 2005 Nov-Dec;53(6):423-32

6. Jaffin RA, Berman $\mathrm{CL}$. The excessive loss of Branemark fixtures in type IV bone: a 5-year analysis. J Periodontol. 1991 Jan;62(1):2-4.

7. Norton MR, Gamble C. Bone classification: an objective scale between the $\mathrm{TI}$ and the ISQ inserted in the mandible and the maxilla of various bone densities $[13,21,24,30]$.

Results of additional studies are divergent from the ones found in this research study, showing that implants can present good primary stability with a standard protocol, in which $\mathrm{TI}$ and ISQ are two independent primary stability characteristics. Data also show that it is only influenced by bone density, as well as the ISQ is correlated with the length of the implants used [28].

Thus, according to the results found in this research study, it can be concluded that the radiomorphometric indexes can be used as a prediction resource considering the initial stability of mplants.

\section{Collaborators}

RA RIBEIRO, researcher responsible, the whole process. JS BARBOSA, image Collection and evaluation of qualitative indexes according to examiner. JMBL AMARAL, collection of clinical data, CR FRANCO, measurement of quantitative índices, ARG GONZALEZ CORTES, search of references and statistical analysis and C COSTA, assistance in the combination of the data and the dissertation of this article.

of bone density using the computerized tomography scan. Clin Oral Implants Res. 2001 Feb;12(1):79-84. doi: 10.1034/j.16000501.2001.012001079.x

8. Whaites E. Radiografia panorâmica: princípios de radiologia odontológica. $3^{\text {a }}$ ed. Porto Alegre: Artmed; 2003. p.174-185.

9. Klemetti E, Kolmakov S, Kröger H. Pantomography in assessment of the osteoporosis risk group. Scand J Dent Res. 1994 Feb;102(1):68-72.

10. Taguchi A, Suei $Y$, Ohtsuka M, Otani K, Tanimoto K, Ohtaki $M$. Usefulness of panoramic radiography in the diagnosis of postmenopausal osteoporosis in women. Width and morphology of inferior cortex of the mandible. Dentomaxillofac Radiol. 1996 Nov;25(5):263-7. doi: 10.1259/ dmfr.25.5.9161180

11. Law AN, Bollen AM, Chen SK. Detecting osteoporosis using dental radiographs: a comparison of four methods. J Am Dent Assoc. 1996 Dec;127(12):1734-42. doi: 10.14219/jada. archive.1996.0134

12. Bollen AM, Taguchi A, Hujoel PP, Hollender LG. Case-control study on self-reported osteoporotic fractures and mandibular cortical bone. Oral Surg Oral Med Oral Pathol Oral Radiol Endod. 2000 Oct;90(4):518-24. doi: 10.1067/moe.2000.107802

13. Taguchi A, Tsuda M, Ohtsuka M, Kodama I, Sanada M, Nakamoto $T$, et al. Use of dental panoramic radiographs in identifying younger postmenopausal women with osteoporosis. Osteoporos Int. 2006;17(3):387-94. 
14. Mudda JA, Bajaj M, Patil VA. A Radiographic comparison of mandibular boné quality in pre- and post-menopausal women in Indian population. J Indian Soc Periodontol. 2010 Apr;14(2):121-5.

15. Costa-Paiva L, Horovitz AP, Santos AO, Fonsechi-Carvasan GA, Pinto-Neto AM. Prevalência da osteoporose em mulheres na pós-menopausa e associação com fatores clínicos. Rev Bras Ginecol Obstet. 2003;5(7): 507-12. doi: 10.1590/S010072032003000700007

16. Kanis JA, Johnell O. Requirements for DXA forthemanagement of osteoporosis in Europe. Osteoporos Int. 2005 Mar;16(3):22938.

17. Devlin H, Horner K. Mandibular radiomorphometric indices in the diagnosis of reduced skeletal bone mineral density. Osteoporos Int. 2002 May;13(5):373-8. doi: 10.1007/ s001980200042

18. Drozdzowska B, Pluskiewicz W, Tarnawska B. Panoramic-based mandibular indices in relation to mandibular bone mineral density and skeletal status assessed by dual energy X-ray absorptiometry and quantitative ultrasound. Dentomaxillofac Radiol. 2002;31(6):361-7. doi: 10.1038/sj.dmfr.4600729

19. White SC, Taguchi A, Kao D, Wu S, Service SK, Yoon D, et al. Clinical and panoramic predictors of femur bone mineral density. Osteoporos Int. 2005 Mar;16(3):339-46. doi: 10.1007/ s00198-004-1692-4

20. Geraets WG, Verheij JG, van der Stelt PF, Horner K, Lindh C, Nicopoulou-Karayianni $K$, et al. Prediction of bone mineral density with dental radiographs. Bone. 2007 May;40(5):121721. doi: 10.1016/j.bone.2007.01.009

21. Groen JJ, Duyvensz F, Halsted JA. Diffuse alveolar atrophy of the jaw (non-inflammatory form of paradental disease) and pre-senile osteoporosis. Gerontol Clin (Basel). 1960;2:68-86.

22. Atsumi M, Park SH, Wang HL. Methods used to assess implant stability: current status. Int J Oral Maxillofac Implants. 2007 Sep-Oct;22(5):743-54.

23. Isoda K, Ayukawa $Y$, Tsukiyama $Y$, Sogo M, Matsushita $Y$, Koyano K. Relationship between the bone density estimated by cone-beam computed tomography and the primary stability of dental implants. Clin Oral Implants Res. 2012 Jul;23(7):8326. doi: 10.1111/j.1600-0501.2011.02203.x
24. Trisi P, De Benedittis S, Perfetti G, Berardi D. Primary stability, insertion torque and bone density of cylindric implant ad modum Brånemark: is there a relationship? An in vitro study. Clin Oral Implants Res.2011 May;22(5): 567-70. doi: 10.1111/j.1600-0501.2010.02036.x

25. Turkyilmaz I, Tözüm TF, Tumer C, Ozbek EN. Assessment of correlation between computerized tomography values of the bone, and maximum torque and resonance frequency values at dental implant placement. J Oral Rehabil. 2006 Dec;33(12):881-8. doi: 10.1111/j.1365-2842.2006.01692.x

26. Klemetti E, Kolmakov S, Heiskanen P, Vainio P, Lassila V. Panoramic mandibular index and bone mineral densities in postmenopausal women. Oral Surg Oral Med Oral Pathol. 1993 Jun;75(6):774-9

27. Klemetti E, Kolmakov S, Kröger H. Pantomography in assessment of the osteoporosis risk group. Scand J Dent Res. 1994 Feb;102(1):68-72.

28. Martinez H, Davarpanah M, Missika P, Celletti R, Lazzara R. Optimal implant stabilization in low density bone. Clin Ora Implants Res. 2001 Oct;12(5):423-32.

29. Makary C, Rebaudi A, Sammartino G, Naaman N. Implant primary stability determined by resonance frequency analysis: correlation with insertion torque, histologic bone volume, and torsional stability at 6 weeks. Implant Dent. 2012 Dec;21(6):474-80. doi: 10.1097/ID.0b013e31826918f1

30. Johansson P, Strid KG. Assessment of bone quality from placement resistance during implant surgery. Int J Ora Maxillofac Implants. 1994;9:279-288. 